\title{
ARTIGO
}

DOI: https://doi.org/10.22481/praxis.v14i29.4112

\section{IN-SERVICE ENGLISH TEACHER EDUCATION FOR DIGITAL ENVIRONMENTS: PERCEPTIONS ON THEORETICAL BASES}

\author{
FORMAÇÃO CONTÍNUA DE PROFESSORES DE INGLÊS PARA AMBIENTES \\ DIGITAIS: PERCEPÇÕES ACERCA DAS BASES TEÓRICAS
}

\author{
FORMACIÓN CONTINUADA DE PROFESORES DE INGLÉS PARA AMBIENTES \\ DIGITALES: PERCEPCIONES ACERCA DE LAS BASES TEÓRICAS
}

Paulo Boa Sorte

Universidade Federal de Sergipe - Brasil

\begin{abstract}
This paper aims at analyzing the perceptions of English teachers about the theoretical bases discussed in a teacher development course named Digital Environments: theory and practice in the classroom. The course, which focuses on promoting digital literacies, is offered by the Federal University of Sergipe (UFS) in partnership with the Undergraduate Center for Distance Education at UFS and the research group E-Lang from UNICAMP. Among the theoretical bases of this study are the authors who discuss the inclusion of digital technologies at schools and English classes as well as the notion of digital literacies (BAWDEN, 2008; BRAGA, 2013; COLL ET AL, 2010; LANKSHEAR \& KNOBEL, 2008; LEMKE, 1998; SANTAELLA, 2013). For data analysis, it is taken into account the messages posted on the platform where the course is offered, i.e. discussion forums and reflective electronic diary. The results show how the participating teachers understand conceptions such as technology, hyperlinks and digital literacies. In addition, it is observed the relevance of discussing issues related to the official guidelines for teaching foreign languages in Brazil, which leads to the need for the teacher to be constantly involved in professional develpoment.
\end{abstract}

Key Words: Professional development. Digital environment. Theoretical bases.

Resumo: Esta pesquisa tem o objetivo de analisar a percepção de professores de inglês acerca dos subsídios teóricos discutidos em um projeto de formação contínua. Intitulado "Ambientes Digitais: na teoria e na prática de sala de aula", o projeto, com foco na promoção de práticas letradas digitais, é oferecido na modalidade semipresencial pela Universidade Federal de Sergipe (UFS) em parceria com o Centro de Educação Superior a Distância da UFS e o grupo de pesquisa E-Lang da UNICAMP. Dentre os fundamentos teóricos deste estudo estão os autores que discutem a inserção das Tecnologias Digitais da Informação e Comunicação na escola e nas aulas de inglês, bem como a noção de letramento(s) digital(is) (BAWDEN, 2008; BRAGA, 2013; COLL ET AL, 2010; LANKSHEAR E KNOBEL, 2008; LEMKE, 1998; SANTAELLA, 2013). Para a análise dos dados, são levados em conta os registros de mensagens na plataforma em que o curso é ofertado, ou seja, em fóruns de discussão e no diário eletrônico reflexivo. Os resultados revelam como os participantes entendem conceitos como, tecnologia, hiperlinks e letramento(s) digital(is). Além disso, percebe-se a relevância de se discutir temas relacionados às diretrizes oficiais do ensino de línguas estrangeiras, levando à necessidade de o professor estar constantemente envolvido em cursos de formação. 
Palavras-chave: Formação do professor de inglês. Ambientes digitais. Subsídios teóricos.

Resumen: Esta investigación tiene el objetivo de analizar la percepción de profesores de inglés acerca de los subsidios teóricos discutidos en un proyecto de formación continua. El proyecto, con foco en la promoción de prácticas letradas digitales, es ofrecido en la modalidad semipresencial por la Universidad Federal de Sergipe (UFS) en asociación con el Centro de Investigación y Desarrollo Educación Superior a Distancia de la UFS y el grupo de investigación E-Lang de UNICAMP. Entre los fundamentos teóricos de este estudio están los autores que discuten la inserción de las Tecnologías Digitales de la Información y Comunicación en la escuela y en las clases de inglés, así como la noción de letramento(s) digital(es) (BAWDEN, 2008; BRAGA, 2013; COLL ET AL, 2010; LANKSHEAR E KNOBEL, 2008; LEMKE, 1998; SANTAELLA, 2013). Para el análisis de los datos, se tienen en cuenta los registros de mensajes en la plataforma en que el curso es ofrecido, es decir, en foros de discusión y en el Diario Electrónico Reflexivo. Los resultados revelan cómo los participantes entienden conceptos como, tecnología, hipertextos y letramentos(s) digital(es). Además, se percibe la relevancia de discutir temas relacionados a las directrices oficiales de la enseñanza de lenguas extranjeras, llevando a la necesidad de que el profesor esté constantemente involucrado en cursos de formación.

Palabras clave: Formación del profesor de inglés. Ambientes digitales. Subsidios teóricos.

\section{Introduction}

English teacher education for the use of digital technologies comprises a broad path that starts with having teachers aware of the changes we are going through, especially when it comes to the way we have been communicating with one another over the past decade. Constant reading, professional development, and reflective practice may help teachers to be engaged in the so-called age of digital technologies.

Since 2015, a professional development course named Digital Environments: Theory and Practice in the Classroom (hereinafter referred to as DETPC) has been taught to public school English teachers in the State of Sergipe, Brazil. It has been carried out by the Foreign Languages Department of Federal University of Sergipe (UFS) in partnership with the research group E-Lang from State University of Campinas (UNICAMP) and Center for Higher Distance Education (CESAD) of UFS - since it is a blended learning program. DETPC aims at promoting critical use of digital technologies among English teachers at public schools. Thus, it provides a theoretical course for teachers to reflect on digital literacies along with practical activities, which aim at producing pedagogical materials using the Internet as the main source. 
The first part of DETPC is the focus of this paper ${ }^{1}$. It aims at analyzing the contributions of theoretical bases from the participating teachers' viewpoint. The analysis is done through the records of messages posted on the virtual environment in which the project takes place - discussion forums and reflective electronic diaries. This paper begins with a brief overview of DETPC. Afterwards, there is theoretical background on Digital Literacies. The research methodology and data analysis are stated hereafter, where the participants of this study are presented, and data were collected and analyzed.

\section{DETPC overview}

DETPC is a free of charge blended professional development course to teachers of English in the State of Sergipe. The duration of the course is 12 weeks. During that period of time, teachers are supposed to do web-based online tasks, and there are also four in-person meetings - when feedback on the online tasks is given, debates on the theoretical bases are held, and the teachers have the opportunity to share their experiences on the practical assignments that they give their students. The classes are delivered throughout three modules, such as follows:

Module 1- Technological changes in the ways we communicate

Module 2 - Education in the $21^{\text {st }}$ century

Module 3 - From theory to practice: the development of a school project

During modules 1 and 2, the participating teachers are supposed to read texts, engage in online discussions forums, watch videos, access websites and applications, and write lesson plans. Module 3, on the other hand, has a more teaching-based purpose: they have to develop a school project using digital technologies based on the tasks they did during the previous modules.

Every week, the teachers are also supposed to write their own reflective electronic diaries. It is a mandatory task in which they write their perceptions on the course as well as on their teaching practice. The reflective electronic diary was designed as a digital version of the reflective diary (BAILEY \& OSCHNER, 1983; BAILEY, 1990). It was thought not only as an instrument of data collection, but also as a resource to provoking reflective teaching and learning, besides being a useful tool for the teacher educators to have feedback on how the course is being taught.

\footnotetext{
${ }^{1}$ This research was conducted during the period of time I spent at State University of Campinas (UNICAMP) as a Post-doctoral researcher under the supervision of Prof. Dr. Denise Bértoli Braga.
} 
The theoretical bases of DETPC (BRAGA, 2013; BUZATO, 2001; ALBUQUERQUE, 2005; PAIVA, 2006; XAVIER, 2010; OLIVEIRA, 2014), focus of this paper, are geared towards the understanding of digital literacies, the impact of the technological tools in our lives, and their relationship with education and the teaching of English.

\section{Theoretical background}

Digital literacies are the main theoretical background of this paper. They go beyond the mastery of technical abilities with digital devices and the Internet. They are related to aspects, such as: knowledge construction from the diversity of sources from websites and trustful data; critical thinking that leads us to awareness of validity and integrity of data found on the Internet; reading and understanding dynamic and non-sequential texts, such as hypertexts; awareness of the value of traditional tools (mechanical technologies) and its relation to digital technologies (BAWDEN, 2008). Therefore, digital literacies are the mastery of technical skills for reading from and on the most varied media associated with awareness of risk factors that the multiple uses of those tools may cause. Buzato (2006), Braga (2007), Lankshear \& Knobel (2008), and Brydon \& Tavares (2013) agree that digital literacies are social practices mediated by mobile devices capable of generating, negotiating and communicating meaning, opening spaces for new and other social relations and knowledge.

From this point of view, English teachers can use the Internet, electronic games or any other type of media to teach. First of all, it is necessary to be aware that those tools do not have merely instrumental functions. Hence, the student needs to be guided towards knowing and criticizing those media at the same time they learn how to use them (BUCKINGHAM, 2008).

The fact is that we are surrounded by a growing number of texts written into various forms of representation. That is what is called multimodality, i.e. printed texts, sounds, images and pictures are part of the contemporary world. The multiplicity of texts follows the cultural multiplicity of populations (LEMKE, 1998; ROJO, 2012). We all need to be part of this world, we need to learn how to read it and capture the senses and meanings that are given. The English teacher sees herself/himself among new ways of writing - such as chats, feeds, links, posts, twits, and hashtags - and needs to use them, since changing also happens in 
social practices. As Braga (2013, p. 40) points it, those changes cause "social demand and not a mere option that is given to individuals". To some teachers, however, it may be scary and resistance is something that needs to be talked about.

Both resistance and easiness of dealing with technology have received researchers' attention along time. They analyze the relationship between society and technology. Saito \& Ribeiro (2013) remind us that Van Tassel (1983) and Campion (1983) name "technophile" and "technophobic" those who, respectively, appreciate and resist to adapting to technological society. Schlindwein (2014) states that resistance to technologies can be observed throughout history, and it is explained partly because of the so-called extreme - often pessimistic discourses on how the future will be transformed by technology. The way people relate themselves with technology depends, moreover, on economic, social and ideological factors.

\section{Research methodology}

Five public school teachers of English from the State of Sergipe, who attended DETPC, participate in this research. All of them are graduated in English language teaching, and their ages vary from 27 through 37 years old. They were chosen randomly because the schools where they teach do not present relevant differences in regard to contextual factors for teaching. All of them use digital technologies outside of school. They have daily access to the Internet as well as profiles on social media, such as Facebook, Instagram and WhatsApp.

The data were collected on the virtual environment where the course takes place. I took into consideration the messages on the online discussion forum as well as their reflective electronic diaries and a questionnaire from a reading activity. The teachers' names are omitted in order to protect participant confidentiality. For identification purposes, the abbreviations $\mathrm{T} 1, \mathrm{~T} 2, \mathrm{~T} 3, \mathrm{~T} 4$ and $\mathrm{T} 5$ are used.

The data analysis focuses on the participating teachers' perceptions on the theoretical bases read and discussed during DETPC. As parameters for data analysis, I use conceptions on digital literacies (GILSTER, 1997; BAWDEN, 2008; BUCKINGHAM, 2008; LANKSHEAR; KNOBEL, 2008; LEFFA; MARZARI, 2013); ubiquitous learning (SANTAELLA, 2013); changes, resistance and appreciation of technologies (TASSEL, 1983; CAMPION, 1983; PAIVA, 2006; SAITO; RIBEIRO, 2013), besides the theoretical bases from DETPC (BRAGA, 2013; BUZATO, 2001; ALBUQUERQUE, 2005; PAIVA, 2006; XAVIER, 2010; OLIVEIRA, 2014). 


\section{Data analysis}

Most of the readings done by the teachers are based on Braga (2013), a book written in Portuguese entitled Ambientes digitais: reflexões teóricas e práticas (in English, Digital environments: theoretical and practical reflections). The point that the author intends to make is the same as DETPC's (since the course is inspired on Braga's book), that is to say, reflections on digital information and communication technologies, especially on using the Internet for reading and writing on digital environments, and their possible uses in Brazilian basic education.

Module 1, named Technological changes in the ways we communicate, focuses on historical aspects of digital technologies evolution. There is emphasis on deconstructing the idea that technologies are just the ones related to computers, mobile devices and the Internet. The readings and debates during the first week of the course show that, in the past, the drawings on cave walls were signs of pre-existing communicative needs, and reflected direct concerns of communities with survival. Since the need to have information circulate increased, it was necessary to come up with tools that could account for doing that service. Thus, technologies such as parchment and papyrus were invented.

On the excerpts from the reflective electronic diaries, the five participating teachers report being surprised with the conceptions of technologies brought to discussion:

It's funny, I had never thought of those objects as technologies. When I thought of technologies, what would come to my mind was PCs, smartphones, tablets, GPS... and I'm amazed to see that they represent an evolution, a new generation of technologies, a new era (EXCERPT FROM T1'S DIARY, my emphasis).

I had never thought of pencils, books or chalks as a technologies. We are used to associating the term technology to machines and electronic equipment. Everything's new in this course, no matter what the "format" is, it requires a process of adaptation and learning (EXCERPT FROM T2's DIARY, my emphasis).

I was surprised to see that the book is a technology! E-books have been playing an important role in the evolution of technology, but I don't think the book will no longer exist someday, so won't the pencil. They play important roles in our society, when there's power shortage, for example (EXCERPT FROM T3'S DIARY, my emphasis).

Before this course, I had never thought of those objects as technologies. The course has been expanding horizons for us to see what's there behind technologies. It's funny to see how the book has evolved, and so has the 
VCR, the TV set, and the cinema (EXCERPT FROM T4'S DIARY, my emphasis).

The tasks we did this week surprised me a lot and made me see that not only the computer, the internet and mobile devices can be considered technologies. The teacher has to be prepared to deal with all sorts of technologies, even the analogical ones (EXCERPT FROM T5'S DIARY, my emphasis).

The fact that the participating teachers are surprised with the conceptions of technologies studied along module 1 is somewhat iterant, as emphasized on the excerpts from their reflective electronic diaries. The introductory part of DETPC seems to be clearly directed towards definitions of technologies, since teachers need to be aware of their history as well as the fact that societies undergo structural changes due to the emergence of different technologies. In this sense, schools needs to absorb the changes that occur over time, and teachers need to be prepared to deal with them.

Another theoretical basis has to do with the differences between literacy and alphabetization - especially when it comes to those terms in Portuguese, i.e. letramentos and alfabetização. In the second week of tasks, the participating teachers read the paper entitled Conceptualizing Literacy and Alphabetization, by Albuquerque (2005). After having read it, they answered a virtual questionnaire that established relationship between their own teaching practices and Albuquerque's ideas. In his/her response to the questionnaire, T5 states his/her understanding on the concept of literacy as something related to social practices of language, describing critical education as a component of that process:

I look to relate my classroom activities to literacies rather than alphabetization, because I feel like it's crucial that the students relate the language that is being taught to the world in a more critical way. What is interesting about it is that it is possible to make use of technology to have students live those social practices, showing them that we need not only to read and write, but that we need to get to know the different senses and meanings of each text available in the world, we need to know many possible ways to read and to be a reader and take a stand in a critical way of what is being seen and heard. (T5'S POST ABOUT THE SECOND WEEK OF TASKS).

Although s/he did not report how s/he relates their classroom activities to literacy practices, T5 made interesting point in the debate. By stating it is necessary that students relate what is being taught / learned to social practices, it can be inferred that s/he assigns tasks whose focus is not only on analyzing grammatical structures but on their relevance to students' everyday lives in social practices of language - a widely discussed topic on National Curriculum Parameters (BRASIL, 1998) and National Curriculum Guidelines for Secondary 
Education (BRASIL, 2006). Therefore, his/her perception about the conceptions from the second week of activities seems to be in line with what has been discussed about literacies in the Brazilian context, that is, they are social practices that generate, negotiate and communicate senses and meanings. This is what T4 reinforces in his/her response to the same activity:

Literacy consists in creating means for the student to respond adequately to social demands of reading and writing. There are moments, in my classroom, which I alphabetize into a literacy perspective. It means that I have students in High School who have almost zero English skills. My goal is not only to teach what is written or to learn a new word, but to identify the context in which it is found and to make some use of it [...] I confess that these conceptions are new to me and that, every week, with every book I read, I am aware of the particular components of the teaching process. Sometimes when reading the texts, I come across things I had always done and I did not know that there was a definition for it. On certain occasions, I see that my teaching could have been influenced or would have been better, if I had read those texts before (T4'S POST ABOUT THE SECOND WEEK OF TASKS).

T4's post reinforces T5's perceptions on literacies as social practice, since they refer to national curriculum demands, which, in its turn, relate to the National High School Examination (ENEM), currently required to enter federal public universities. There are new conceptions of teaching, according to the participating teachers, that focus on the preparation for ENEM, and prioritize questions that involve knowledge construction from students' experiences in practical situations of their lives. In other words, it assesses the candidates' abilities to use knowledge constructed during their school lives through problem solving. By saying that $s /$ he alphabetizes "into a literacy perspective", T4 may be justifying his/her assertion of students having "almost zero English skills". From ENEM's perspective, it is necessary that students not only decode what is written but also identify the contexts in which texts are produced.

The participating teachers frequently reported that the theories from DETPC were new to them. In regard to digital literacies studies, the course also highlights the conceptions of multimodality, hypertext, and hybridization of languages, which are central to the production and reading of hypermedia texts. During the week when the conception of hypertext was studied, the teachers' posts on the reflective electronic diaries show their findings on links, as shown on T5's and T2's posts below:

This week's topic was hypertexts, their meanings, their rhetorical functions and the construction of meanings. I realized that when we understand what it 
is about, it allows us to reflect on the paths that our students take while reading on the web and the possibilities of constructing meaning from the links he follows and from those who, in his logic, passes over. It was interesting to learn about the presence of the hypertext in other media, such as the cinema. In my teaching practice, I will try to explore, in a better way, the possibilities of the hypertext, but I'm thinking of using the students' cell phones, since we cannot count on computers (EXCERPT FROM T5'S DIARY).

If DETPC finished today, I would still be glad I came! It's funny how we are exposed to hypertexts and links every day, and despite the fact that information is easy to access, sometimes it's hard to come up with lesson plans using hypertexts. This week's activities were really important and useful to me (EXCERPT FROM T2'S DIARY).

According to the participating teachers, it was valid to reflect on hypertexts - dynamic and non-sequential materials that characterize changes in the processes of reading and writing that we go through. As Xavier (2010) points it, those changes are explained by the increasing use of digital technologies.

Some teachers found it hard to work with hypertexts. Throughout the week in which they were to set up such a task, tutors and DETPC coordinators received many messages asking for more examples of how to make hyperlinks. Some of them also requested a face-toface meeting in order to address such questions. From what the teachers reported, I believe that it is also possible that they might have experienced two phases of the incorporation of technological tools in the pedagogical practices claimed by Paiva (2006): the adoption by curiosity, followed by skepticism after facing the first obstacles; and a new attempt after being convinced by someone (in this case, the tutors) that it might be worth assigning tasks with hyperlinks. On their diaries, despite the moments of apprehension, difficulties and insecurity, $\mathrm{T} 3$ and $\mathrm{T} 1$ seem to have been able to accomplish the tasks:

At first I was a little apprehensive about the exercise, I thought I was not able to perform the task; I thought I would have to create a page or blog with a subject. After watching the video, I got it, and I did research, and I found a website on how to create a hypertext. Doing this week's activity for me was very positive, since I had never done any exercise or content with hypertexts, nor did I know what it was. I had already noticed in texts that certain prominent words gave access to another page. Now I know that the possibilities of using hypertexts in classroom activities are endless (EXCERPT FROM T3'S DIARY).

This was the hardest week so far, because I didn't know how to do this hyperlink task. It's something that we see a lot, and even click when it appears in the texts, but I didn't even think about how I could teach with them. I almost gave up on this activity. I looked for help and it worked. I was 
very insecure, and I'm still not sure if it is correct, I'm waiting for the tutors' feedback (EXCERPT FROM T1'S DIARY).

The difficulties reported by T3 above, when s/he mentions, "I thought I was not able to perform the task; I thought I would have to create a page or blog with a subject", and T1, when s/he writes "I was very insecure, and I'm still not sure if it is correct, I'm waiting for the tutors' feedback" are examples of obstacles that teachers undergo when they try to adopt technologies in their teaching. Paiva (2006) claims that they embrace innovation because they are curious, but curiosity is replaced by disbelief at the first barriers. Having tried to do the activity without any help, teachers might probably give up, as they would not have the support offered by DETPC tutors. That is why in-person meetings and discussion forums are so relevant in professional development, especially if it has blended learning methodology.

Reflections on the theoretical bases were also present in the discussion forum. The following post is related to T1's participation, when they were asked to talk about the critical use of technologies in schools:

\begin{abstract}
I would like to start by quoting Braga, when she asks "how can we consider curriculum and teaching methods so they can meet technological changes and we can promote means of thinking critically?" Based on my teaching experience, I can say that while there's no participation of school management team along with teachers, education will continue to be a make believe. I tell you that because there are many schools in Sergipe equipped with computer labs that don't work, they serve as storage rooms. On one side, teachers do nothing to solve this problem; on the other side, public policies don't care about maintenance or training. They just buy computers and store them in schools. Meanwhile, teachers are worried about improving their teaching practices. We just have to suit ourselves with the stuff we have (EXCERPT FROM T1'S POST ON THE DISCUSSION FORUM).
\end{abstract}

T1's school does not seem to get attention from the authorities. His/her complaints also concern lack of computer labs maintenance, which may prevent them from having students engaged in digital literacies. There seems to be a circular problem here, that is to say, schools have computer labs, but there is no maintenance, because there is no maintenance, teachers do not use those labs, and because they do not use labs, they do not feel the need to ask for it from the management team, and so on.

On the same forum, T5, besides summarizing the theoretical debate, also related his/her teaching practice to the public school system in Sergipe. Even with the circular problems that they face, such as the one from the previous excerpt, they can envision agency by encouraging students to use their phones for doing research and sharing contents: 
According to Braga (2013), "changes are not determined by media, but by the pedagogical perspective that the teacher pursues as well as the effective and creative exploitation of resources that his or her pedagogical perspective has got to offer". Therefore, in order to have critical use of digital technologies in addition to the remarks made here by my classmates, we need to leave aside the naivety of thinking that technologies solve of all the problems involving the processes of teaching and learning. A critical use comprehends the way in which certain contents need to be worked. During all of this week's reading materials, we have seen that it is possible to "kill" your student by showing endless power point slides. In order to motivate them, it takes more than a few effects on a computer screen. Teachers don't need to hide themselves behind the technological resources. They only need to find clear objectives. Since I started working as a public school English teacher, I have been encouraging my students to use their cell phones to search for knowledge, whether through online surveys, content sharing, or the use of offline dictionary applications. Despite the resistance of some and the difficulty of others, it is gratifying to see that they became autonomous by combining the use of a laptop, cell phones and my support to build their own learning. They even correct me when I make a mistake, because they can check spellings and meanings quickly (EXCERPT FROM T5'S POST ON THE DISCUSSION FORUM).

By encouraging students to use their own cell phones in the classroom, T5 seems to suggest that the presence of digital technologies in the classroom, as stated by Coll et al. (2010), can promote changes in traditional educational settings. The teacher is not the only source of knowledge and, as far as foreign language classes are concerned, the source of translation. His/her rule needs to be instructing them into various possibilities of accessing and interpretating information that is available both online and offline. T5 also seems to be aware that technological evolution has become personalized, focused on the user and on mobile devices. This way, learning also becomes a little more individualized, learner-centered and ubiquitous (SANTAELLA, 2013).

In general, with regard to the DETPC's theoretical bases, one can affirm that the participating teachers deconstructed conceptions about technologies that are still widespread in common sense - such as technologies are only computers, mobile devices and smartphones. However, one can still notice that there is resistance in using certain tools, especially if teachers face difficulties in their first attempt. On the other hand, the opportunities for discussion provided by professional development courses, such as DETPC, may help them to reduce resistance and make the use of digital technologies much more invisible and standardized (PAIVA, 2006). As Prata-Linhares and Silva (2015) point it, professional development is more than an isolated action. It is a permanent process, which requires collective, institutional, social, political, economic, ethical and aesthetic commitment. 


\section{Final remarks}

Teaching at Brazilian public schools can be a big challenge because working conditions are precarious. Schools that should be prepared to support students in digital literacy practices do not even have reasonable Internet connection. Depending on the school, there are no computers, and when they exist, there is no maintenance. In the midst of complex contexts such as those, many questions arise, for instance, how can we overcome structural problems that have socio-historical roots?

Engaging in professional development, doing reflective practice, stating clear objectives to our classes, and demanding better work conditions from local authorities can be a good start. The participating teachers are statistically different from those who are resistant to the use of technologies. They want to learn and look for professional development in order to become part of the increasingly digital society.

It is true that during the weekly activities, tutors and coordinators could notice that some teachers were looking for recipes or "magic formulas" to teach English with technologies. This search is, most of the times, stimulated by the powerful publishing market, especially the one directed to foreign language teachers.

The participating teachers' perceptions regarding theoretical bases from DETPC reinforce the need for the English teacher, or teachers from any subject matter, to be constantly involved in professional development. As I have stated on other occasions (BOA SORTE, 2014, 2015), teacher education should occur as a process - not a product - of professional and personal development. It needs to involve teachers and teacher educators in permanent critical reflection, which must be political, and geared towards wide access to technologies and quality teaching of languages, in general, and English, in particular.

\section{REFERENCES}

ALBUQUERQUE, Eliana Borges Correia de. Conceituando alfabetização e letramento. In: SANTOS, C.; MENDONÇA, M. (Org). Alfabetização e letramento: conceitos e relações. Belo Horizonte: Autêntica, 2005, p. 11-21.

BAWDEN, David. Origins and concepts of Digital Literacy. In: Lankshear \& Knobel. Digital Literacies. New York: Peter Lang, 2008, p. 17-32. 
BAILEY, Kathleen. An introspective analysis of an individual's language learning experience. In: BAILEY, Kathleen. Issues in second language acquisition: selected papers of the Los Angeles second language research forum. Rowley, Mass: Newbury House, 1990.

BAILEY, Kathleen; OCHSNER, Robert. A methodological review of the Diary Studies: windmill tilting or social science? In: BAILEY, Kathleen; OCHSNER, Robert. (Org). Second language acquisition studies. Rowley, Mass: Newbury House, 1983.

BOA SORTE, Paulo. Sobre diretrizes, realidades e possibilidades: problematizando a formação em Letras-Inglês no Brasil. In: SANTOS, E. F. et al. (Org). Atravessando línguas e linguagens. Aracaju-SE: EDIFS, 2014.

BOA SORTE, Paulo. Investigando os saberes práticos de sobrevivência. In: The ESPecialist: pesquisa em línguas para fins específicos: v.35. n1.p. 7-26, 2015.

BRAGA, Denise Bértoli. Práticas Letradas Digitais: considerações sobre possibilidades de ensino e de reflexão social crítica. In: ARAÚJO, J. C. (Org). Internet \& Ensino: novos gêneros, outros desafios. Rio de Janeiro: Lucerna, 2007, p. 181-195.

BRAGA, Denise Bértoli. Ambientes Digitais: reflexões teóricas e práticas. 1.ed. São Paulo: Cortez, 2013.

BRASIL. Ministério da Educação. Secretaria de Educação Básica. Parâmetros Curriculares Nacionais: línguas estrangeiras modernas. Brasília: MEC/ SEB, 1998.

BRASIL. Ministério da Educação. Secretaria de Educação Básica. Orientações Curriculares para o Ensino Médio. Brasília: MEC/ SEB, 2006.

BRYDON, Diana; TAVARES, Roseanne Rocha. Letramentos transnacionais: mobilizando conhecimento entre Brasil/Canadá. Maceió: EDUFAL, 2013.

BUCKINGHAM, David. Defining digital literacy. In: LANKSHEAR, Colin; KNOBEL, Michele. Digital Literacies: concepts, policies and practices. Philadelphia: Open University Press, 2008, p. 73-89.

BUZATO, Marcelo. O letramento eletrônico e o uso do computador no ensino de língua estrangeira: contribuições para a formação de professores. 189 f. Dissertação (Mestrado em Linguística Aplicada e Estudos da Linguagem), Universidade Estadual de Campinas, Campinas-SP, 2001.

BUZATO, Marcelo. Letramentos Digitais e Formação de Professores. In: Anais do Congresso Ibero-Americano EducaRede, 2006. São Paulo: CENPEC, 2006, p.81-86. 
COLL, Cesar. et al. Os ambientes virtuais de aprendizagem baseados na análise de casos e na resolução de problemas. In: COLL, Cesar; MONERO, Carles. (Orgs). Psicologia da Educação Virtual: aprender e ensinar com as tecnologias da informação e comunicação. Tradução de Naila Freitas. Porto Alegre: Artmed, 2010, p. 189-207.

GILSTER, Paul. Digital fusion: defining the intersection of contente and communications. In: MARTIN, Alan; MADIGAN, Dan. Digital literacies for learning. London: Facet, 1997, p. 42-50.

LANKSHEAR, Colin; KNOBEL, Michele. Digital Literacies: concepts, policies and practices. Philadelphia: Open University Press, 2008.

LEFFA, Vilson José; MARZARI, Gabriela Quatrin. O letramento digital no processo de formação de professores de línguas. In: Revista de Educação, Ciência e Tecnologia. Canoas-RS, v.2. n.2, p. 1-18, 2013

LEMKE, Jay. Metamedia literacy: transforming meanings and media. In: REINKING, D. et al. (Org). Handbook of literacy and technology: transformations in a post-typographic world. Hillsdale: erlbaum, 1998, p. 139-301.

OLIVEIRA, Alexandra Aparecida de. A prática docente de língua inglesa para estudantes surdos e ouvintes usando o livro didático e o computador: um estudo de caso sob a ótica da Teoria da Atividade. 222f. Dissertação (Mestrado em Educação), Universidade Federal de Lavras, Lavras-MG, 2014.

PAIVA, Vera Lúcia Menezes de Oliveira e. O uso da tecnologia no ensino de línguas estrangeiras: breve retrospectiva histórica. In: 7o Encontro do CELSUL (Centro de Estudos Linguísticos do Sul), 2006, Pelotas. Programação e Resumos. Santa Maria: Gráfica Editora Pallotti, 2006. p. 68-68.

PRATA-LINHARES, Martha Maria; SILVA, Ketiuce, Ferreira. Tecnologias digitais de informação e comunicação na formação inicial de professores: em busca de práticas inovadoras. Revista Tempos e Espaços em Educação, São Cristóvão, v.8, n.17, p. 133-143, 2015.

ROJO, Roxane. Pedagogia dos multiletramentos: diversidade cultural e de linguagens na escola. In: ROJO, R.; MOURA, E. (Org). Multiletramentos na escola. São Paulo: Parábola, 2012, p. 11-32.

SAITO, Fabiano Santos; RIBEIRO, Patrícia Nora de Souza. (Multi)letramento(s) digital(is) e teoria do posicionamento: análise das práticas discursivas de professoras que se relacionaram com as tecnologias da informação e comunicação no ensino público. In: Revista Brasileira de Linguística Aplicada, Belo Horizonte, v.13. n.1, p. 37-65, 2013. 
SANTAELLA, Lúcia. Comunicação ubíqua: representações na cultura e na educação. São Paulo: Paulus, 2013.

SCHLINDWEIN, Ana Flora. You tell stories, we click on them: Ciberliteratura(s) e novas experiências na criação de histórias. 227f. Tese (Doutorado em Linguística Aplicada).

Universidade Estadual de Campinas, Campinas-SP, 2014.

XAVIER, Antônio Carlos. Leitura, texto e hipertexto. In: XAVIER, A. C.; MARCUSCHI, L. A. (Org). Hipertexto e gêneros digitais: novas formas de construção de sentido. 3.ed. São Paulo: Cortez, 2010, p. 207-220.

\section{SOBRE O AUTOR:}

\section{Paulo Boa Sorte}

Ph.D. in Applied Linguistics from the Pontifical Catholic University of Sao Paulo, Brazil. Professor at the Undergraduate Program of Foreign Languages and Graduate Program of Education at the Federal University of Sergipe, Brazil. Fulbright Visiting Scholar at the University of Michigan/ School of Education, USA (January through May, 2017). E-mail: pauloboasorte1@gmail.com 